\title{
SUSTAINABILITY REPORT AND FIRM PERFORMANCE: STUDY IN MINING AND METAL AND FOOD PROCESSING INDUSTRY INDONESIA STOCK EXCHANGE 2014- 2017
}

\author{
Tri Gunarsih ${ }^{1, *}$ and Yuni Ismawati ${ }^{1}$ \\ ${ }^{1}$ Faculty of Economic and Business, Universitas Teknologi Yogyakarta, Indonesia
}

ABSTRACT - The aim of this study is to give empirical evidence about the effect of three disclosure dimensions of Sustainability Reporting (SR) to firm performance using ROA and Tobin's $Q$. The three dimensions of SR consist of economic dimension, environment dimension, and social dimension. The argument of the relationship between SR and companies' performance in this study is developed base on good management theories that argues that there is a high correlation between good management practice and Corporate Social Performance (CSP), then there will be a positive impact of SR on the company's performance. The sample of this study comprise of 60 listed companies in IDX in 2014-2017, in mining and metal and food processing industries. The sampling method is purposive sampling. The results show two dimensions of SR (economic dimension and social dimension) has an impact on market value (Tobin's $Q$ ) but not on book value (ROA).
ARTICLE HISTORY

Received: 18-09-2018

Accepted: 12-11-2018

\section{KEYWORDS}

Sustainability reporting, Firm performance, Economic dimension, Environment dimension, Social dimension

\section{INTRODUCTION}

Sustainability Reporting (SR) is widely used to communicate the companies' effect on social, environmental and economic performance. According to Global Reporting Initiative (GRI, 2016), SR, as promoted by the GRI Standards, is an organization's practice of reporting publicly on its economic, environmental, and/or social impacts, and hence its contributions - positive or negative - towards the goal of sustainable development. Before 2016, GRI published GRI G4.

Sustainable development is 'development which meets the needs of the present without compromising the ability of future generations to meet their own needs' (World Commission on Environment and Development, 1987, as in GRI, 2016). This suggests that in achieving the company's performance, they should in line with sustainable development.

The arguments of the relationship between SR and companies' performance in this study is developed base on good management theorist. Good management theorists argue, that there is a high correlation between good management practice and CSP, simply because attention to CSP domains improves relationships with key stakeholder groups (e.g. Freeman, RE 1984 as in Waddock and Graves, 1997) resulting in better overall performance. This positive relationship not only in internal company's factors such as a good relationship with the employee that will enhance productivity and satisfaction, but also positive customer perception about the quality and nature of companies' effect on social, environmental and economic performance and its contributions towards the goal of sustainable development. Based on this theory then there will be a positive impact of SR on the company's performance.

Some empirical studies found that SR has a positive impact to firm performance (Hayatun and Rahmanti, 2012; Kusuma \& Koesrindartoto, 2014; Diantimala, 2018; Amacha \& Dastane, 2017), some others found that there isn't any impact of SR to firm performance (Utami, 2015 and Ching et al.,2017) and the other is mixed (Aggarwal, 2013).

Those empirical studies show that there is no clear consensus as to whether the financial performance of companies relates to their sustainability performance. This study gives empirical evidence about SR and firm performance base on Indonesia data, in mining and metals industry and manufacturing industry, especially in food processing sector.

The sector disclosure of GRI G4 that was launched in May 2013 covered construction and real estate, electric utilities, financial sector, food processing, mining and metals, NGO and Oil and Gas. The company in Mining and metals has a high risk of the safety of human resources, natural resources and has responsibility for social life, while the company in the manufacturing sector, especially in the food and processing industry, has a high role in social and environmental life, such as responsibility for the waste produced and human resource safety and natural resource safety.

\section{LITERATURE REVIEW}

\section{Sustainability Reporting}

SR is prepared base on The Global Reporting Initiative (GRI) Standards. The GRI Standards are structured as a set of interrelated standards. They have been developed primarily to be used together to help an organization prepare a 
Sustainability Reporting which is based on the Reporting Principles and focuses on material topics (GRI, 2016). Before 2016, GRI published GRI G4.

The GRI G4 Guidelines was launched in May 2013. The sector disclosure of GRI G4 covered construction and real estate, electric utilities, financial sector, food processing, mining and metals, NGO and Oil and Gas. The Global Reporting Initiative (GRI) is a non-governmental organization that develops and disseminates globally Acceptance Sustainability Reporting Standards. The GRI started in 1997 as an initiative of the United Nations Environment Program and became independent in 2002. The GRI develops the sustainability reporting standards guidelines through a multi-stakeholder process that incorporates the active participation of business, accountancy, investment, environmental, human rights, research, and labour organizations from around the world.

\section{Sustainability Reporting in Indonesia}

SR in Indonesia is regulated base on the Financial Service Authority (FSA) regulation number 51/POJK.03/2017 concerning sustainable financial services for financial services institutions, emissions and public companies on July, 18th, 2017. In line with the GRI standards, FSA regulates SR. It requires companies to give an overview of Sustainability Aspect Performance and provide a comparison of the performance of the last 3 (three) years or lesser depending on when the company is operating. Three elements namely economic, environmental and social aspects are needed to be disclosed.

Economic aspect, include: (i) quantity of production or services sold; (ii) income or sales; (iii) net profit or loss; (iv) environmentally friendly products; and (v) involvement of local parties related to the business process of Sustainable Finance.

Environmental aspect, include: (i) energy use (including electricity and water); (ii) emission reductions produced (for FSI, Issuers, and Public Companies whose business processes are directly related to the Environment); (iii) reduction of waste and effluent (waste that has entered the environment) produced (for FSI, Issuers, and Public Companies whose business processes are directly related to the Environment); (iv) preservation of biodiversity (for FSI, Issuers, and Public Companies whose business processes are directly related to the Environment). Social aspect requires a description of the positive and negative impacts of the implementation of Sustainable Finance for the community and the environment (including people, regions and funds).

FSA made it mandatory for financial service institutions companies with year ending 1 January to 31 December 2019 for financial service institutions in the form of BUKU 3, BUKU 4, and foreign banks; and with year ending January 1 to December 31, 2020 for financial services institutions in the form of BUKU 1 and BUKU 2, finance companies, Islamic finance companies, venture capital companies, sharia venture capital companies, infrastructure finance companies, insurance companies, sharia insurance companies, reinsurance companies, companies sharia reinsurance, Indonesian Export Financing Agency, housing secondary financing company, Social Security Organizing Body, Issuers other than issuers with small-scale assets and issuers with medium-scale assets, as well as public companies. This regulation should be obeyed by the company.

\section{Sustainability Reporting and Performance Studies}

Waddock and Graves (1997) found that there is a high correlation between both SR disclosure and performance. This could be because corporate social performance will improve relationships with key stakeholders' groups, resulting in better overall performance.

Empirical studies have shown inconsistent results. Some support the positive relationship between SR and firm performance, others do not. Aggarwal (2013) examines the impact of sustainability rating of company on its financial performance in an Indian context using secondary data Four key components of sustainability (i.e. Community, Employees, Environment and Governance) were examined. The results show that there is no significant association between overall sustainability rating and financial performance but further analysis reveals that the four components of sustainability have significant but varying impact on financial performance.

The empirical studies that do not support positive relationship between SR and firm performance are Ching et al. (2017) with Brazilian listed companies and Utami (2015) using Indonesian Stock Exchange data. Ching et al. (2017) show that there is no association between accounting and market-based variables and the reporting quality. The quality disclosure is improving throughout the years studied (year 2008 to 2014) but the scores are still low. Utami (2015) examine the influence of leverage, profitability, and the quality of sustainability disclosures on firm value with revenues growth as moderating variable. The quality of sustainability was measured based on the disclosure index and the firm's value was measured using Tobin's Q. The results show that the quality of sustainability disclosure does not have a significant influence on firm value and revenue growth has a role as moderating variable that makes the relationship between quality of sustainability disclosure and firm value is stronger. This suggests that even there is no direct effect between the quality of sustainability disclosure to firm value, but this effect is strengthened by revenue growth. The higher the revenue growth, the stronger the relationship between the quality of sustainability disclosure and firm value.

Some empirical studies that support the positive relationship between SR and firm performance are Hayatun and Rahmanti (2012), Kusuma and Koesrindartoto (2014), Diantimala (2018) and Amacha and Dastane (2017). Amacha and Dastane (2017) investigate the relationship between sustainability practices and performance in a financial sense for Malaysian Oil and Gas sector. Sustainability performance is measured using ACSI checklist, which is an adaptation of the GRI 3.0 by Global reporting initiative while financial performance was measured on financial and profitability parameters namely EBITDA, EPS and PE ratio. The results show that on all three chosen profitability parameters, the 
companies that practiced sustainability were found to perform better than their counterparts that did not. Strong and significant relationship exists between sustainability practices and better financial performance.

Hayatun and Rahmanti (2012) examine the relationship between sustainability reporting as a whole and each of the elements of sustainability reporting with company performance. The samples consist of 32 companies listed on Indonesian Stock Exchange during the period of the year 2006-2009. The result shows that sustainability reporting influences company performance. However, partially, only social performance disclosure influences the company performance.

Other study that supports the argument positive relationship is Kusuma and Koesrindartoto (2014), investigates empirical evidence of the correlation between sustainability practices and financial performance in Indonesian companies. The ESG (Environmental, Social, and Government) indicator is used as a proxy for the level of sustainability practices. Financial performance is measured by a set of financial ratios, especially in profitability. The results show that there is a positive relationship between the value of sustainability and profitability ratios, namely ROA, ROE, ROIC, and EBITDA margins. The other is Diantimala (2018), that examine the effect of financial performance on sustainability disclosure and then to examine the effect of sustainability disclosure on firm value. It is predicted that lower leverage and higher firm size, higher liquidity, as well as higher profitability will motivate companies' management to convey more their sustainability disclosure. The higher sustainability disclosure increases firm value significantly.

\section{METHODOLOGY}

\section{Sample selection}

Samples in this study are public companies, listed in the Indonesia Stock Exchange between 2014-2017. The samples are selected using purposive sampling, based on the following criteria:

1. $\quad$ Listed in the Indonesia Stock Exchange between 2014-2017

2. The Sustainability Reporting data and financial data are available for the reporting year ending 2014- 2017.

The criterias is used to compute the sustainability index and financial performance variables.

3. The sample firms publish audited financial statements using reporting period ended on December 31 .

\section{Measurement Variables}

\section{Dependent Variables}

The dependent variables of this study are Tobin's Q and Return on Assets (ROA). Tobin's Q as a market firm performance's measurement, computed using the following formula:

$$
\text { Market value of equity }+ \text { book value of debt }
$$

Tobin's Q $(\mathrm{TQ})=\frac{\text { Book value of total asset }}{\text { Where: }}$

Where:

Market value of equity : stock outstanding $\mathrm{x}$ closing price

Book value of debt $\quad$ : book value of debt at the end of fiscal year

Book value of total asset : book value of total asset at the end of fiscal year

Return on Assets (ROA) measures operational performance and is computed using the following formula:

$$
R O A=\frac{\text { Net income }}{\text { total assets }}
$$

ROA= Return on Assets

The positive relationship with the employee will enhance productivity and satisfaction, which will improve efficiency and profitability of a company which is measured by ROA. The positive customer and investor perception about the quality and nature of companies will have an effect on the social, environmental and economic performance and this in turn will contribute towards the goal of sustainable development and will improve market value, which is measured by Tobin's Q. Previous studies have used both measurements to measure performance of a company and this study uses both measurements. It will be interesting to find out whether SR will have an impact on ROA and /or Tobin's Q. 


\section{Independent variables}

Independent variables in this study are three dimensions of sustainability, they are economic dimension, environment dimension and social dimension. Those variables measured base on Sustainability Reporting Disclosure Index (SRDI) GRI-G4, consist of 91 items of total disclosures in Sustainability Reporting. SRDI each dimension computed using following formula:

a. Economic dimension

$$
S R D I_{\text {economic }}=\frac{\mathrm{n}}{k}
$$

Where:

$S R D I_{\text {economic }}=$ Sustainability Reporting Disclosure Index economic dimension $\mathrm{n}=$ number of economic dimensions disclosed by the company

$\mathrm{k}=$ total item of economic dimension (9 items)

b. Environment dimension

$$
S R D I_{\text {environment }}=\frac{n}{k}
$$

Where:

$S R D I_{\text {environment }}=$ Sustainability Reporting Disclosure Index environment dimension

$\mathrm{n}=$ number of environment dimension disclosed by the company

$\mathrm{k}=$ total item of environment dimension (34 items)

c. Social dimension

$$
S R D I_{\text {social }}=\frac{n}{k}
$$

Where:

$S R D I_{\text {social }}=$ Sustainability Reporting Disclosure Index social dimension

$\mathrm{n}=$ number of social dimensions disclosed by the company

$\mathrm{k}=$ total item of social dimension (48 items)

\section{Regression Analysis}

This study tested the research question using regression as follows.

$$
\begin{aligned}
& \text { ROA }=\alpha+\beta_{1} X_{1}+\beta_{2} X_{2}+\beta_{3} X_{3}+\varepsilon \\
& \text { TQ }=\alpha+\beta_{1} X_{1}+\beta_{2} X_{2}+\beta_{3} X_{3}+\varepsilon
\end{aligned}
$$

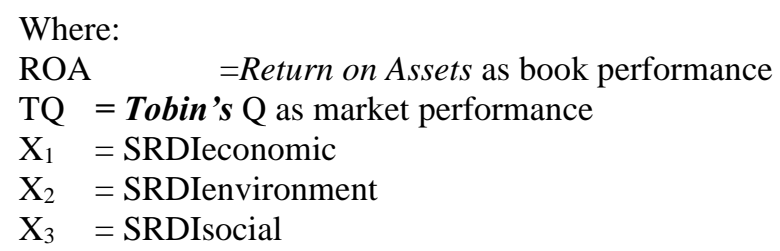

Some tested are conducted to get BLUE (Best Linear Unbiased Estimator) estimator. They are: (1) normality using Kolmogorov-Smirnov Z (1-Sample $K$-S), (2) Multicollinierity, if the value of Tolerance $\leq 0,10$ or the value of VIF $\geq 10$, then there are no serious multicollinierity problems, and (3) Heteroscedasticity test using glejser test.

\section{RESULTS}

Table 1 shows the descriptive statistics of independent (SRDIec, SRDIenv \& SRDIsoc) and dependent variables (ROA and Tobin's Q).

Table 1. Descriptive Statistics

\begin{tabular}{lccccc}
\hline Variable & $\mathrm{N}$ & Minimum & Maximum & Mean & Std. Deviation \\
\hline \hline SRDIec & 60 & 0.11 & 1.00 & 0.41 & 0.22 \\
SRDIenv & 60 & 0.05 & 0.97 & 0.34 & 0.19 \\
SRDIsoc & 60 & 0.06 & 0.89 & 0.28 & 0.18
\end{tabular}




\begin{tabular}{|c|c|c|c|c|c|}
\hline Variable & $\mathrm{N}$ & Minimum & Maximum & Mean & Std. Deviation \\
\hline ROA & 60 & -0.56 & 1.62 & 0.21 & 0.27 \\
\hline Tobin's Q & 60 & 0.30 & 22.89 & 2.69 & 4.54 \\
\hline
\end{tabular}

The mean of SRDIec is 0.41 or $41 \%$. This suggests that the average economic dimension disclosed from 9 indicators is $41 \%$. PT Bukit Asam Tbk in 2015 has the highest number (1). This suggests that this company disclosed all of the indicators ( 9 indicators or $100 \%$ ) as guided by GRI G4 in economic dimension.

The mean of SRDIenv is 0.34 or $34 \%$. This number shows that the average of environment dimensions disclosed from 34 indicators guided by GRI G4 is 34\%. PT Bukit Asam Tbk has the highest number (0.97 or 97\%). This company disclosed 33 from 34 indicators as guided by GRI G4 in environment dimension.

The mean of SRDIsoc is 0.28 or $28 \%$. This number shows that the average of social dimensions disclosed from 48 indicators guided by GRI G4 is $28 \%$. PT Bukit Asam Tbk. has the highest number of social disclosure. This company disclosed 43 from 48 social indicators or 0.89 (89\%).

Figure 1 shows the average number of SRDIec, SRDIenv and SRDIsoc year 2014-2017. The highest number of 3 indicators are in 2015, while the lowest are in 2017. Since the SR mandatory as regulated by FSA is in 2019, then the average number will increase in the near future, especially in the financial industry.

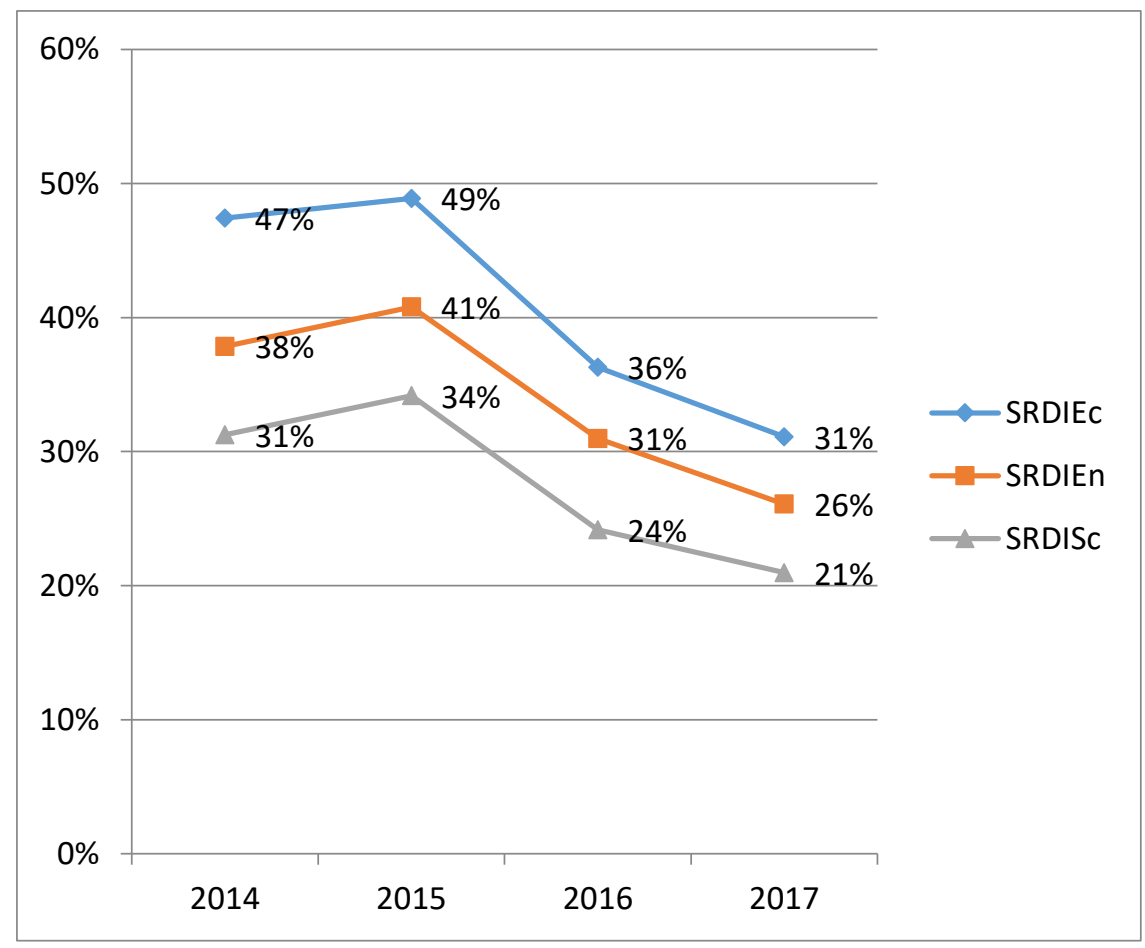

Figure 1. Average SRDIec, SRDIenv and SRDIsoc 2014-2017

\section{Regression Analysis}

Table 2 shows the regression analysis as model (6) and (7). The F value of model (6) and (7) are 3.78 and 5.55 respectively, while the significance level is $5 \%$ and $1 \%$. These suggest that both models are fit even not of the $t$ values are statistically significant.

All of the $t$ value in the model (6) is not statistically significant. These suggest that there is no relationship between SR performance base on economic dimension, environment dimension and social dimension to ROA.

The $t$ value of SRDIec, SRDIenv, and SRDIsoc in model (7) are 2.86, 0.65 and 2.75 respectively. Two variables are statistically significant at 5\% levels, they are SRDIec and SRDIsoc, while SRDIenv is not statistically significant. These suggest that there is relationship between SRDIec with firm performance and between SRDIsoc with firm performace. 
Table 2. Regression analysis

\begin{tabular}{llcc}
\hline & & ROA (model 6) & TQ (model 7) \\
\hline \hline Constant & Beta & -0.05 & 1.77 \\
& t value & -0.71 & 1.84 \\
SRDIec & Sig. & 0.48 & 0.072 \\
& Beta & 0.12 & -5.86 \\
& t value & 0.91 & 2.86 \\
SRDIenv & Sig. & 0.37 & 0.01 \\
& Beta & 0.08 & 2.10 \\
& t value & 0.29 & 0.65 \\
SRDIsoc & Sig. & 0.78 & 0.52 \\
& Beta & 0.17 & 5.48 \\
& t value & 1.01 & 2.75 \\
& Sig. & 0.32 & 0.01 \\
& F value & 3.78 & 5.55 \\
& Sig. & 0.02 & 0.00 \\
& R square & 0.17 & 0.56 \\
\hline
\end{tabular}

\section{Normality test}

Table 3 shows the result of the normality test to meet the requirement of parametric statistics, based on the OneSample Kolmogorov-Smirnov Test. The t statistic of One-Sample Kolmogorov-Smirnov Test is 0.08 , statistically not significant (sig value $>0.05$ ). This suggests that the data are normally distributed.

Table 3. One-Sample Kolmogorov-Smirnov Test

Unstandardized Residual

\begin{tabular}{llc}
\hline \hline $\mathrm{N}$ & & 60 \\
Normal Parameters $^{\mathrm{a}, \mathrm{b}}$ & Mean & -0.64 \\
& Std. Deviation & 0.28 \\
Most Extreme Differences & Absolute & 0.08 \\
& Positive & 0.07 \\
& Negative & -0.08 \\
Test Statistic & & 0.08 \\
Asymp. Sig. (2-tailed) & & 0.20 \\
\hline
\end{tabular}

\section{Multicollinearity test}

The result of multicollinearity test is in table 4. Table 4 shows that all of the VIF (Variance Inflation Factor) is less than 10 (VIF < 10.00) and the value of tolerance are more than 0.10 (tolerance $>0.10)$. These suggest that there are no serious multicollinearity problems the both in regression models.

Table 4. Multicolinierity test

\begin{tabular}{ccccc}
\hline \multirow{2}{*}{ Model } & \multicolumn{2}{c}{ ROA } & \multicolumn{2}{c}{ Tobin's Q } \\
& Tolerance & VIF & Collinearity Statistics \\
& 0.42 & 2.39 & 0.42 & VIF \\
\hline \hline SRDIec & 0.39 & 2.59 & 0.38 & 2.39 \\
SRDIen & 0.33 & 2.99 & 0.33 & 2.59 \\
SRDIsoc & 0.42 & 2.39 & 0.42 & 2.99 \\
SRDIec & & & 2.39 \\
\hline
\end{tabular}

\section{Heteroscedasticity test}

Heteroscedasticity test is conducted to test whether there is inequality of variance and residual in regression model in one observation to another. The result of this test using glejser test is as in Table 5. Since the sig value is more than 0.05 (sig. > 5\%) then there is no heteroscedasticity problem in both model (model $6 \&$ model 7). 
Table 5. Heteroscedasticity

\begin{tabular}{lcc}
\hline Variable & Residual value (model 6) & Residual value (model 7) \\
\hline \hline & Sig. & Sig. \\
SRDIec & 0.50 & 0.14 \\
SRDIen & 0.07 & 0.06 \\
SRDIsoc & 0.07 & 0.67 \\
\hline
\end{tabular}

\section{DISCUSSION}

\section{SR and book value of firm performance}

The regression model (6) examines the impact of SR disclosure to book value of firm performance. Even the model is statistically significant, but there is no independent variable that is statistically significant. This suggests that there is no relationship between all the dimensions of SR with firm performance. It seems that there is no positive relationship between SR and the employee that will enhance productivity and satisfaction. One of the possible explanation is that the awareness of SR importance is still low. Then the SR has no impact to efficiency and profitability.

This result is consistent with the study conducted by Ching et al. (2017) and Utami (2015). Ching et al. (2017) show that there is no association between accounting (book value) and market-based variables and the reporting quality in Brazilian listed companies. This suggests that SR performances (economic dimension, environment dimension and social dimension) do not impact firm performance directly. Other possibility that need to be tested is whether the firm that has well financial performance will impact SR performances since SR performance need high financially supports. Utami (2015) uses companies listed on Indonesian Stock Exchange and found no significant relationship between SR (quality of sustainability disclosure) and performance (firm value).

\section{SR and market value of firm performance}

The regression model (7) examines the impact of SR disclosure to the market value of firm performance. The model is fit at $1 \%$ level and two of the independent variables are statistically significant at $1 \%$ levels, they are SRDIec and SRDIsoc, but unfortunately, SRDIenv is not significant. The results show that there is a relationship between SRDIec and SRDIsoc with the market value of firm performance but there is no relationship between SRDIenv with market value. These suggest that not all of the SR has a relationship with market value. The possible explanation is that there is less awareness in all of the SRDI item. Then the campaign of SR importance is necessary. This study supports Hayatun and Rahmanti (2012), Kusuma and Koesrindartoto (2014), Diantimala (2018) and Amacha and Dastane (2017), even though not all of the three dimensions of SR. The SR performances (economic dimension and environment dimension in this study) have impact to market firm performance, but do not have impact to book performance.

\section{CONCLUSION}

This study gives empirical evidence about SR (GRI G4) and firm performance base on accounting/book performance (ROA) and market performance (Tobin's Q) in Indonesia year 2014-2017. The results show that both model (SR and ROA and SR and Tobin's Q) are statistically significant, but all of the independent variables in the three dimensions of SR and ROA are not statistically significant. Two dimensions of SR and Tobin's Q are statistically significant. These suggest that there is a relationship between SR and market firm performance but there is no relationship between SR and book value firm performance.

These suggest that there is a relationship between SR and market firm performance but there is no relationship between SR and book value firm performance. This raise an interesting question. One explanation could be that SR is not mandatory and thus the awareness of SR importance is still low. Further studies can be carried out by examining the SR with the book and market value firm performance, especially when SR has become mandatory for the company.

\section{REFERENCES}

Aggarwal, Priyanka. (2013). Impact of Sustainability Performance of Company on its Financial Performance: A Study of Listed Indian Companies. Global Journal of Management and Business Research Finance, 13 (11), 60-70.

Amacha, Ezeoha Bright and Omkar Dastane. (2017). Sustainability Practices as Determinants of Financial Performance: A Case of Malaysian Corporations. Journal of Asian Finance, Economics and Business, 4 (2) 55-68.

Ching Hong Yuh, Fábio Gerab, and Thiago Henrique Toste. (2017). The Quality of Sustainability Reports and Corporate Financial Performance: Evidence from Brazilian Listed Companies. SAGE Open, April-June, 1-9.

Diantimala, Yossi. (2018). The Mediating Effect of Sustainability Disclosure on the Relationship between Financial Performance and Firm Value. Journal of Accounting, Finance and Auditing Studies, 4 (2), 32-48.

Financial Sevices Authority. (2017). Regulation of Financial Services Authority No. 51/POJK.03/2017 on Application of Sustainable Finance to Financial Services Institution, Issuer and Publicly Listed Companies. 
Freeman, RE. (1984). Strategic Management, A Stakeholder Approach. Pitman Publishing Inc, Massachusetts. GRI. (2016). GRI 101: Foundation, Global Sustainability Standards Board (GSSB), Amsterdam.

Hayatun, Annisa N. Burhan and Wiwin Rahmanti. (2012). The impact of sustainability reporting on company performance. Journal of Economics, Business, and Accountancy Ventura 15 (2), 257 - 272.

Kusuma, Ainia P.A. and Deddy P Koesrindartoto. (2014). Sustainability Practices and Financial Performance: An Empirical Evidence from Indonesia. International Conference on Trends in Economics, Humanities and Management (ICTEHM'14) Aug 13-14, (Thailand).

Utami, Wiwik. (2015). Financial Performance and the Quality of Sustainability Disclosure Based on Global Reporting Initiative: Value Relevances Study in Indonesia Stock Exchange. Mediterranean Journal of Social Sciences, 6 (5), 243-248.

Waddock, Sandra A. and Samuel B. Graves. (1997). The corporate social performance financial performance link. Strategic Management Journal, 18(4), 303-319.

World Commission on Environment and Development. (1987). Our Common Future. Oxford: Oxford University Press 